\title{
Genetic enhancement of pearl millet and sorghum for the semi-arid tropics of Asia and Africa
}

\author{
K.N. Rai, D.S. Murty, D.J. Andrews, and P.J. Bramel-Cox
}

\begin{abstract}
Sorghum (Sorghum bicolor (L.) Moench) and pearl millet (Pennisetum glaucum (L.) R. Br.), ranking fifth and sixth in global cereal hectarage, respectively, are the most important coarse-grain cereals in the semi-arid tropical regions of Asia and Africa. Pearl millet displays better adaptation to and is grown in relatively more marginal environments than sorghum. Under subsistence farming conditions, both crops have low grain yields $\left(0.5-0.7 \mathrm{t} \cdot \mathrm{ha}^{-1}\right.$ for pearl millet and $0.7-0.9 \mathrm{t} \cdot \mathrm{ha}^{-1}$ for sorghum), although improved hybrid cultivars give $3-4 \mathrm{t} \cdot \mathrm{ha}^{-1}$ of realizable grain yields in better-endowed environments. African germplasm, especially Zera Zera sorghums from the Sudan-Ethiopian border in eastern Africa and Iniari pearl millets from the Togo - Ghana - Benin - Burkina Faso region of western Africa, has proved most useful for the genetic improvement of these crops. The greatest impact of improved cultivars (mostly hybrids) has occurred in India, where the area under high-yielding varieties (HYVs) increased from 6\% for pearl millet and 3\% for sorghum in the triennium 1968-1970 to 53\% for pearl millet and 54\% for sorghum in the triennium 1992-1994. During the same period, productivity of both crops increased by 59\%, which is attributable to both genetic improvement and management factors. HYVs have now started to be adopted in some of the African countries as well (e.g., Chad, Cameroon, Botswana, and Zimbabwe for sorghum; Chad, Namibia, Zambia, and Zimbabwe for pearl millet). The availability of vast untapped genetic resources and continuing yield gains indicate that there are good prospects for future genetic improvement in the productivity of these crops, which can be accelerated with the application of biotechnological tools. Sorghum and pearl millet will continue to be important food crops in their traditional semi-arid tropical areas. Sorghum is already an important feed crop in the developed world and pearl millet has the potential to become an even better feed crop, as it has higher protein content and a better amino acid profile than sorghum. The nutritional value of both crops for food and feed use can be further improved by breeding. Also, through genetic enhancement, there exist opportunities for the development of sorghum and pearl millet cultivars suitable for alternative uses in the bakery and beverage industries.
\end{abstract}

Key words: sorghum, Sorghum bicolor, pearl millet, Pennisetum glaucum, genetic enhancement, semi-arid tropics, Asia, Africa, cultivars, impact.

Résumé : Le sorgho (Sorghum bicolor (L.) Moench) et le millet pearl (Pennisetum glaucum (L.) R. Br.) occupent le cinquième et sixième rangs, respectivement, en terme de superficies cultivées en céréales et sont les plus importantes céréales dans les régions tropicales semi-arides de l'Afrique et de l'Asie. Le millet pearl montre une meilleure adaptation et il est cultivé dans des environnements un peu plus marginaux que ne l'est le sorgho. En conditions d'agriculture de subsistance, ces deux cultures offrent de faibles rendements $\left(0,5-0,7 \mathrm{t} \cdot \mathrm{ha}^{-1}\right.$ pour le millet pearl et $0,7-$ $0,9 \mathrm{t} \cdot \mathrm{ha}^{-1}$ pour le sorgho) alors que des cultivars hybrides améliorés offrent un potentiel de $3-4 \mathrm{t} \cdot \mathrm{ha}^{-1}$ dans des environnements plus favorables. Le germoplasme africain, surtout les sorghos Zera Zera de la frontière sudanoéthiopienne en Afrique de l'Est et les millets pearl Iniari des régions occidentales (Togo - Ghana - Bénin - Burkina Faso) s'est avéré le plus utile pour l'amélioration génétique de ces espèces. L'impact le plus grand des cultivars améliorés (surtout des hybrides) s'est fait sentir en Inde où les superficies occupées par des variétés à haut rendement (HYV) sont passées de $6 \%$ pour le millet pearl et $3 \%$ pour le sorgho (en 1968-70) à $53 \%$ pour le millet pearl et $54 \%$ pour le sorgho (en 1992-94). Pendant cette même période, la productivité des deux cultures s'est accrue de 59\%, une augmentation attribuable à la fois à l'amélioration génétique et aux pratiques culturales. Des variétés à haut rendement ont commencé à être adoptées dans certains pays d'Afrique également (par exemple au Chad, au Cameroun, au Botswana et au Zimbabwe pour le sorgho et au Chad, en Namibie, en Zambie et au Zimbabwe pour le millet pearl).

Corresponding Editor: R.S. Singh.

Received June 9, 1998. Accepted April 8, 1999.

K.N. Rai ${ }^{1}$ and P.J. Bramel-Cox. Genetic Resources and Enhancement Program, International Crops Research Institute for the Semi-arid Tropics (ICRISAT), Patancheru 502 324, Andhra Pradesh, India.

D.S. Murty. Maharashtra Hybrid Seeds Company Limited, Research and Development, Kallakal, 502 334, Andhra Pradesh, India. D.J. Andrews. Department of Agronomy, University of Nebraska, Lincoln, NE 68583-0519, U.S.A.

${ }^{1}$ Author to whom all correspondence should be addressed. 
La disponibilité d'immenses ressources génétiques inexploitées et des gains constants sur le plan du rendement suggèrent de belles perspectives pour l'amélioration future de la productivité de ces cultures, laquelle pourrait être encore accélérée par le recours aux outils biotechnologiques. Le sorgho et le millet pearl continueront d'occuper une place importante en alimentation humaine dans les régions tropicales semi-arides où elles sont traditionnelles. Le sorgho est déjà une importante culture pour l'alimentation du bétail dans les pays développés et le millet pearl a le potentiel de devenir une culture supérieure en raison de sa forte teneur en protéines et de son meilleur profil d'acides aminés. La valeur nutritive des ces deux cultures tant pour l'alimentation humaine qu'animale peut être accrue encore davantage par amélioration génétique. De plus, l'amélioration génétique pourrait permettre de développer des cultivars de sorgho et de millet pearl adaptés à des utilisations alternatives dans les industries de la boulangerie et des breuvages.

Mots clés : sorgho, Sorghum bicolor, millet pearl, Pennisetum glaucum, amélioration génétique, tropiques semi-arides, Asie, Afrique, cultivars, impact.

[Traduit par la Rédaction]

\section{Introduction}

Pearl millet (Pennisetum glaucum (L.) R. Br.) is a predominantly cross-pollinated crop with $75-80 \%$ outcrossing. In contrast, sorghum (Sorghum bicolor (L.) Moench) is a predominantly self-pollinated crop with 2-20\% outcrossing. Both are important coarse-grain cereals in the drier regions of the world. Sorghum is grown on 45 million ha annually and ranks fifth in global cereal hectarage. Pearl millet is grown on 26 million ha and ranks sixth in global cereal hectarage. Sorghum is relatively more widespread than pearl millet, being cultivated in 86 countries of the tropical, subtropical, and warm-temperate regions of the world. India, China, Sudan, Ethiopia, Niger, Nigeria, Burkina Faso, Mali, the Central African Republic, Mexico, and the U.S.A. account for $75 \%$ of the global grain sorghum hectarage. India accounts for $>80 \%$ of the 12 million ha in Asia under pearl millet cultivation, and seven countries (Niger, Nigeria, Mali, Burkina Faso, Senegal, Chad, and Sudan) account for $>80 \%$ of the 14 million ha under cultivation in Africa.

Both sorghum and pearl millet are $\mathrm{C}_{4}$ species with high photosynthetic efficiency and dry matter production ability, and yet the grain yields of both crops, largely under subsistence farming in much of semi-arid tropical Asia and Africa, are low: $700-900 \mathrm{~kg} \cdot \mathrm{ha}^{-1}$ for sorghum and $500-700 \mathrm{~kg} \cdot \mathrm{ha}^{-1}$ for pearl millet. Low soil fertility, rain-fed farming characterized by erratic and inadequate rainfall (annual precipitation as low as $300 \mathrm{~mm}$ for pearl millet and $600 \mathrm{~mm}$ for sorghum), negligible external inputs, continued use of mostly unimproved cultivars with a low harvest index $(<20 \%)$, and the prevalence of diseases and insect pests are the major causes of low productivity. Under these conditions, yields of maize become too uncertain, and sorghum and pearl millet stand out as the most reliable food cereals. Pearl millet, in general, occupies drier parts of the semi-arid tropics and extends into the arid zone, where soils tend to be more sandy, the growing season shorter, and drought stress more frequent.

The cultivation of improved cultivars, especially hybrids, in environments better endowed with respect to soil fertility and moisture availability gives higher grain yields. For instance, the average grain yields of sorghum cultivars maturing in 100-120 days are as high as $3.4 \mathrm{t} \cdot \mathrm{ha}^{-1}$ in Mexico, 4.1 $\mathrm{t} \cdot \mathrm{ha}^{-1}$ in China, and $4.3 \mathrm{t} \cdot \mathrm{ha}^{-1}$ in the U.S.A. High grain yields $\left(3.5 \mathrm{t} \cdot \mathrm{ha}^{-1}\right)$ of pearl millet hybrid cultivars with a harvest index of about $40 \%$ and maturing in 75-80 days have been reported for irrigated summer crops (main crop in the rainy season) in Gujarat State in India and in the southeastern and midwestern U.S.A. (Rai et al. 1997b).

In Africa and the developing countries of Asia, sorghum and pearl millet grains are used mostly for human consumption. Traditionally these grains are used in such diverse food types as leavened and unleavened flat breads, porridges, steamed foods, and rice-like boiled products and in alcoholic as well as non-alcoholic beverages (Murty and Kumar 1995). Sorghum and pearl millet flours can be substituted for up to $20 \%$ of the wheat flour in making leavened bread. Outside the developing world, sorghum grain is predominantly used as animal feed, and pearl millet grain could have similar uses. The feed value of pearl millet grain is greater than that of sorghum and comparable with that of maize (Andrews and Kumar 1992). Sorghum and, to some extent, pearl millet have the potential for several alternative uses, for which technologies are better developed in sorghum than in pearl millet.

Sorghum and pearl millet are also useful forage crops, and their stover is used for fodder, fencing, thatching, and fuel purposes. Stalks of juicy "sweet sorghum" have additional uses in syrup and alcohol production. However, genetic improvement of sorghum and pearl millet for these attributes has been limited. This paper will deal primarily with genetic enhancement aimed at increasing and stabilizing grain yields, but will also address those aspects of grain quality traits that bear directly on farmers' preferences. The emphasis throughout will be on the semi-arid tropical areas of Asia and Africa.

\section{Genetic resources}

The genus Sorghum has been classified into 48 taxa (Snowden 1936). De Wet (1978) simplified the classification on the basis of ploidy levels and interfertility relationships, and amalgamated all the cultivated races and their interfertile diploid wild and weedy forms into a single species, Sorghum bicolor $(2 n=20)$. Cultivated sorghum, along with its diploid wild subspecies Sorghum bicolor ssp. verticilliflorum (Steud.) Piperand, its diploid weedy form (Sorghum bicolor ssp. drummondii Steud.), and two tetraploid rhizomatous perennial species, Sorghum halepense (Linn.) Pers. and Sorghum propinquum (Kunth.) Hitche., constitute the section Eusorghum. Both tetraploid species freely hybridize with the cultivated diploid species and produce obnoxious 
Table 1. Sorghum and pearl millet germplasm collections in major gene banks. ${ }^{a}$

\begin{tabular}{|c|c|c|c|c|c|c|}
\hline \multirow[b]{3}{*}{ Origin } & \multicolumn{4}{|c|}{ Sorghum } & & \\
\hline & \multicolumn{2}{|c|}{ ICRISAT } & \multicolumn{2}{|c|}{ NPGS } & \multicolumn{2}{|c|}{ Pearl millet (ICRISAT) } \\
\hline & $\begin{array}{l}\text { No. of } \\
\text { accessions }\end{array}$ & $\begin{array}{l}\text { No. of } \\
\text { countries }\end{array}$ & $\begin{array}{l}\text { No. of } \\
\text { accessions }\end{array}$ & $\begin{array}{l}\text { No. of } \\
\text { countries }\end{array}$ & $\begin{array}{l}\text { No. of } \\
\text { accessions }\end{array}$ & $\begin{array}{l}\text { No. of } \\
\text { countries }\end{array}$ \\
\hline Africa & 22985 & 40 & 20392 & 41 & 12531 & 33 \\
\hline Asia & 9503 & 15 & 7668 & 16 & 8338 & 7 \\
\hline Europe & 526 & - & 501 & - & 61 & - \\
\hline Unknown & 63 & & 879 & & 10 & \\
\hline Total & 35643 & & 40477 & & 21191 & \\
\hline
\end{tabular}

${ }^{a}$ Summarized from Eberhart et al. (1997).

weeds. All these taxa constitute the primary gene pool of Sorghum. The remaining species of Sorghum that come under the sections Parasorghum, Chaetosorghum, Stiposorghum, and Heterosorghum form the tertiary gene pool. The cultivated races under $S$. bicolor ssp. bicolor have been classified into five basic races (bicolor, durra, guinea, caudatum, and kafir) and their 10 derived hybrid races (Harlan and de Wet 1972).

The genus Pennisetum is much larger than Sorghum, consisting of more than 140 species of various ploidy levels that display annual and perennial life cycles and sexual, asexual, and apomictic reproductive behavior (Hanna 1987). Sexual reproduction through outbreeding is the most common mode of reproduction in cultivated pearl millet and its wild and weedy relatives. On the basis of crossability relationships and following the biological concept of species (Harlan and de Wet 1971), Pennisetum germplasm has been classified into three gene pools. The primary gene pool includes all the cultivated forms, their wild progenitor (Pennisetum glaucum ssp. violaceum (= monodii Maire)), and its weedy form (Pennisetum glaucum ssp. stenostachyum Kloyasch ex. A. Br., and Bouche), all diploid with $2 n=14$. Elephant or napiergrass (Pennisetum purpureum Schumach.), an allotetraploid $(2 n=4 x=28)$ and rhizomatous perennial, is the only species in the secondary gene pool. All the remaining species form the tertiary gene pool. Based on seed shape, cultivated pearl millet has been classified into four basic races (typhoides, nigritarum, globosum, and leonis) (Brunken et al. 1977), although intermediates between any two of these basic types also exist.

The International Crops Research Institute for the Semiarid Tropics (ICRISAT) and the National Plant Germplasm System (NPGS) of the United States maintain the two largest world collections of Sorghum and Pennisetum germplasm. About $60 \%$ of the total germplasm of both genera in these gene banks is from 40-42 African countries, with another $20-40 \%$ from $24-28$ countries in Asia (Table 1). A sizeable portion of the sorghum germplasm also comes from the Americas, but this is basically introductions from Africa and Asia. In contrast, ICRISAT is the only major repository of Pennisetum germplasm. Its holdings in 1997 included 21191 accessions from 49 countries, of which 20503 were cultivated types, 334 were ssp. monodii, and the remaining 354 comprised 22 other species. Over half of this collection is from diverse geographical areas of Africa, stretching from
Table 2. Range of variation for grain yield components in sorghum and pearl millet.

\begin{tabular}{llc}
\hline & \multicolumn{2}{c}{ Range } \\
\cline { 2 - 3 } Character & Sorghum $^{a}$ & Pearl millet $^{b}$ \\
\hline Days to flowering & $36-199$ & $33-159$ \\
Plant height (cm) & $55-655$ & $30-480$ \\
Productive tillers (no.) & $-c$ & $1-19$ \\
Panicle length (cm) & $3-71$ & $5-120$ \\
Panicle girth (mm) & $10-290$ & $8-58$ \\
1000-grain mass (g) & $3-86$ & $2-21$ \\
\hline${ }^{a}$ Stenhouse et al. 1997. & \\
${ }^{b}$ Rai et al. 1997a. \\
$\quad{ }^{c}$ No data.
\end{tabular}

South Africa to Somalia in the east and Senegal in the west. Western Africa is the primary center of diversity for pearl millet. The Indian subcontinent is the secondary center of diversity, and accessions from diverse agro-ecological areas of India constitute $93 \%$ of the total pearl millet germplasm from Asia in this collection. Besides ICRISAT, there are few other centers that have sizeable holdings of Pennisetum germplasm; there are three gene banks in the U.S.A. with a total of 6637 accessions (including 805 accessions of 31 wild relatives) (Hanna and Lovell 1995), ORSTOM (Institut Français de Recherche Scientifique pour le Développement en Coopération) at Bondy in France (2700 accessions), and ISRA at Bambey in Senegal (2400 accessions) (Rai et al. 1997a).

Ecogeographical adaptation, coupled with intense human selection for diversified needs, has led to substantial differentiation among sorghum and pearl millet landraces. Cultivated landraces of both crops display a wide range of variation for days to flowering, plant height, and yield components (Table 2). Owing to its allogamous breeding behavior, landraces of pearl millet display much larger withinpopulation genetic variation than sorghum populations.

\section{Production constraints and genetic enhancement prioritization}

Poor productivity for grain yield of unimproved cultivars of both sorghum and pearl millet is related to their low harvest index; numerous biotic stresses, including diseases, insect pests, and Striga; and abiotic stress factors, such as 
heat, drought, and low soil fertility. Clearly, all these factors cannot be addressed with the same priority at any given time by breeding. The relative impact of production constraints on yield loss is the primary criterion in research prioritization. However, when it comes to genetic enhancement, the probability of success can be affected by a complex interplay of several factors, such as availability of genetic resources, inheritance and stability of the traits desired to be improved, simplicity and effectiveness of screening techniques (reliability and cost-effectiveness), access to test environments, and availability of technical manpower and material resources, that also become determinants, sometimes of overriding importance.

Breeding for high and stable grain yield with an improved harvest index continues to be the top priority in all sorghum and pearl millet programs wordwide, because $(i)$ impressive yield gains through cultivar improvement, especially in hybrids, have been made in the past and there are no indications that yield ceilings have been reached, (ii) the available germplasm provides vast genetic variability for yield components and adaptation traits, of which only a fraction, even from the cultivated types, has been utilized, (iii) understanding of the inheritance of most of the characters is sufficient for utilization, (iv) evaluation procedures (including effective use of visual assessments) are relatively simple to use, and $(v)$ breeding for most of these these traits requires no special environments.

Drought is the most devastating production constraint that can occur at any crop growth stage in both sorghum and pearl millet. Postflowering (terminal or end of the season) drought stress is of greater significance and is much better understood than preflowering drought stress in both crops. For instance, the crop growth that occurs during the postflowering period in pearl millet has been demonstrated to be the most sensitive to water deficits (Mahalakshmi and Bidinger 1985) and terminal drought has been shown to reduce grain yield by $45-49 \%$ with large variation among genotypes (Fussell et al. 1991). Panicle threshing percentage under stress conditions is a good indicator of terminal drought tolerance in pearl millet. In conjunction with grain yield potential and earliness, it accounts for $>80 \%$ of the genotypic variation in grain yield under terminal drought stress (Bidinger and Mahalakshmi 1993). However, published information confirming the existence of adequate variability for drought-tolerance parameters and adequate repeatable heritability of the trait(s) associated with drought resistance is still lacking. Also, the effectiveness of the screening techniques available for selecting for drought tolerance has not been demonstrated convincingly in terms of how material selected for superior performance in a drought nursery at one location will perform under drought stress at another location. In comparison, in sorghum, the stay-green (slow senescence) trait under drought conditions has proved to be highly heritable and is associated with postflowering drought tolerance. This trait has been used with some success in drought-tolerance breeding in Australia and the U.S.A. (Rosenow et al. 1997). Some other characters that are supposed to be associated with higher yield under terminal drought include faster grain filling, earliness, and reduced stalk lodging. While the approach of escape through earliness has succeeded in pearl millet, it has aggravated grain mold problems in sorghum. Targeted breeding with respect to these drought resistance-tolerance traits has not yet become an integral part of most of the sorghum and pearl millet breeding programs in Asia and Africa, except for selecting for higher grain yields under natural drought environments in which earliness becomes an important selection criterion.

Pearl millet downy mildew, caused by Sclerospora graminicola (Sacc.) J. Schröt, presents a clear contrast to drought. Its impact on pearl millet production, in a global context, is secondary to that of drought, even though downy mildew epidemics on single-cross hybrids have occurred repeatedly in India and can be expected to occur on such cultivars in Africa as well. Breeding for resistance to downy mildew, however, has been accorded the highest priority among the biotic stress factors (Hash et al. 1997), and it is an integral part of a majority of the breeding programs in India (especially at ICRISAT-Patancheru) and Africa, because $(i)$ a large number of resistance sources (including elite breeding lines) have been identified in diverse genetic backgrounds and effective screening techniques have been developed (Singh et al. 1997) and (ii) inheritance of resistance is better understood, with most of the evidence in favor of resistance being dominant and displaying continuous variation in segregating populations (Singh 1995). Over the years, many centers in the National Agricultural Research Systems have initiated or stepped up their downy mildew resistance breeding activities. On a global scale, breeding for grain mold in sorghum has been accorded the highest priority, like downy mildew in pearl millet. However, the success rate has been disappointing, because grain mold is caused by a complex of parasitic fungi (species of Fusarium, Curvularia, Phoma, and Colletotrichum) that damage endosperm and saprophytic fungi (species of Aspergillus and Cladosporium) that affect the pericarp. Mold resistance sources are mostly red or brown grain types, which are associated with high tannins and (or) phenolic compounds such as flavan-4-ols. A few good resistance sources with red grain types have been found in tannin-free backgrounds (Bandyopadhyay et al. 1988). In white grain sorghums, moderate levels of resistance are available only in hard endosperm backgrounds. Associations such as these have deterred the incorporation of mold resistance into early-maturing and large-seeded white grain sorghums with high grain yield.

Other biotic constraints have received relatively low priority in both sorghum and pearl millet breeding programs targeted to the semi-arid tropical regions of Asia and Africa. These can be grouped into two categories.

The first category includes anthracnose (Collitotrichum graminicola (Ces.) Wils.), leaf blight (Exserohilum turcicum Leo and Sug.), and leaf spot (Cercospora sorghi Ellis and Everhert), diseases of sorghum; ergot (Claviceps fusiformis Lovelesse) and smut (Moesziomyces penicillariae (Bref.) Vánky), diseases of pearl millet; midge (Stenodiplosis sorghicola Coquillett)) and head bugs (Calocoris and Eurystylus species), insect pests of sorghum; and the root parasite Striga hermonthica (Del.) Benth. of sorghum. For these, good resistance sources and effective screening techniques have been developed (Sharma et al. 1991, 1993; Thakur et 
al. 1992, 1993; Pande et al. 1994; Ejeta et al. 1997). However, these have been shown not to have as large an impact on yield, on as large a geographical scale, as either grain mold of sorghum or downy mildew of pearl millet. Also, some of these can, to some extent, be managed by other means, for instance, by breeding for improved male fertility restoration in hybrids and by resorting to alternative cultivar options (e.g., open-pollinated varieties (OPVs), topcross hybrids, and protogyny-based single-cross hybrids (seed produced using protogynous flowering rather than by male sterile seed parents) can be effective in reducing ergot and smut severity in pearl millet). Crop losses due to $S$. hermonthica can be considerably reduced in both crops through the use of trap and catch crops, and through various cultural practices (Lagoke et al. 1991).

The second category includes stem borers of both sorghum (species of Busseola, Eldana, Sesamia, and Chilo) and pearl millet (Coniesta ignefusalis Hampson); shoot fly (Atherigona soccata Rodani) and ergot (Claviceps africana, Frederickson, Mantle, and de Milliano) of sorghum; and head miner (Heliocheilus albipunctella de Joannis), Striga, and seedling thermotolerance of pearl millet, for which confirmed sources of good resistance are not available and (or) the trait inheritance is too complex to permit its effective utilization in breeding. This category has received little attention in breeding programs in Asia and Africa.

\section{Breeding approaches}

Sorghum and pearl millet breeding approaches at various centers have taken into account the geographical mandate of individual research organizations, their material and manpower resources, and their short-term and long-term goals with respect to increasing productivity and genetic diversification. This has influenced the extent of germplasm utilization, the breeding methods used, prioritization of target traits, and a consideration of alternative cultivar options (especially in pearl millet).

\section{Germplasm utilization}

In the tropics, a large proportion of the cultivated germplasm of both sorghum and pearl millet flowers irrespective of the day length, although their flowering is delayed to various extents at day lengths of $>12 \mathrm{~h}$. This is loosely known as photoperiod insensitive germplasm, which is, in fact, only less sensitive to day length, and is also known as facultative photoperiod sensitive germplasm. The remaining germplasm, largely originating from equatorial Africa, is highly photoperiod sensitive: it remains vegetative under long days and flowers only when it is exposed to a sufficient number of nights longer than a specific threshold value. This germplasm is actually obligate photoperiod sensitive. In both crops, the general pattern of germplasm utilization (like any other crop) is to search first for desired variability within the less photoperiod sensitive group, and then access the more photoperiod sensitive cultivated types and wild types in the primary, secondary, and tertiary gene pools, in that order. A dramatic decline in the expression of many growth-related characteristics is observed when photoperiod-sensitive germplasm is grown under continuous short days. Thus, photoperiod-insensitive germplasm has found much wider use in breeding programs than sensitive germplasm.

Selection by plant breeders within pearl millet landraces, which have far greater intrapopulation variability than sorghum landraces, has produced improved OPVs, but these have had limited gains in productivity. This is for several reasons: $(i)$ the yield superiority of improved versions has generally been within $15 \%$ over the unimproved landraces, (ii) the improved versions do not provide anything perceptibly different from the unimproved landraces with regard to visual appeal and quality, and (iii) improved versions have as restricted adaptation as the original landraces and, hence, are less suitable for wide adoption and large-scale public sector seed production schemes. These improved landraces have been used by more traditional farmers and distributed through informal seed exchange.

Pearl millet germplasm has been used most in developing composites, which include a wide range of germplasm and improved breeding lines, mostly from western and southern Africa (Rai and Anand Kumar 1994). Pearl millet composites, unlike sorghum composites, were primarily intended for breeding OPVs. Most programs dedicated to breeding hybrid parents in both crops have used pedigree breeding. This approach continues to be successful, although the genetic base of hybrids and hybrid parents in both crops has narrowed considerably, and broadening the genetic base of elite hybrid parents by expanded use of new germplasm is essential for long-term progress in hybrid development.

As and when new material proves its worthiness, it finds increasing use in breeding programs. For instance, several Zera zera sorghums, from the Sudan-Ethiopian border, and their conversion products (SC 108-3, SC 110, and SC 170 (developed at the United States Department of Agriculture, Texas Agricultural Experiment Station), CS 3541 (developed in India), and E 35-1) have been extensively used worldwide. These sorghums are particularly useful in that they are less sensitive to photoperiod, have good general combining ability and excellent grain quality, and are resistant to several diseases and insect pests (Andrews and Bramel-Cox 1993). Similarly, Iniadi germplasm from the Togo - Ghana Burkina Faso - Benin region of western Africa is being most extensively used in pearl millet breeding programs wordwide (Andrews and Anand Kumar 1996), presenting a scenario akin to the Zera zera sorghums. Typical characteristics of this germplasm are large-sized grain $\left(15-18 \mathrm{~g} \cdot 1000^{-1}\right)$ of globular shape and dark grey color with bright outer exposed surface, starchy endosperm, compact and conical panicles, relatively less photoperiod-sensitive earliness (7085 days to mature), rapid grain-filling (23-25 days relative to 25-32 days for others), good downy mildew resistance, and good combining ability for grain yield. A majority of hybrids in India include some degree of Iniadi germplasm in their parental lines, and almost all the hybrids under advanced testing in the U.S.A. include a great deal of it. This germplasm is being increasingly introgressed into a large number of composites. Unstructured large-scale introgression of this germplasm (and, to some extent, of several other germplasms) in both crops runs the risk of disrupting heterotic patterns, if any, in improved breeding materials and, hence, reduces the probability of producing high- 
yielding hybrids in the future. Indeed, this is an area of concern and considerable research in germplasm utilization in both crops. Photoperiod sensitive germplasm accessions have been little used in breeding programs outside their area of adaptation. This is because ( $i$ ) the trait needs have been largely met from within the vast less-sensitive group, of which only a small fraction has been used so far, and (ii) the high attrition rate in segregating generations derived from sensitive $\times$ insensitive crosses has led to few successful outcomes. A large number of photoperiod-sensitive sorghums have already been converted into less-sensitive forms at the Texas Agricultural Experiment Station and at ICRISAT. In pearl millet, a similar conversion program has been initiated at ICRISAT to bring this group of materials into more utilizable form. The utilization of wild germplasm has received the least attention in both crops. However, a modest attempt at Tifton, Georgia to use wild pearl millet germplasm has produced interesting results, as revealed in the utilization of rust and leaf spot resistance and cytoplasmic male sterility from Pennisetum glaucum ssp. monodii accessions, greater stalk strength and male fertility restorer genes from $P$. purpureum, and apomictic genes from Pennisetum squamulatum (Hanna 1992). It has been shown that wild sorghum germplasm can contribute useful variability to highly adapted grain hybrid parents and that introgression through populations is a more effective way of moving this variability than through elite inbred lines (Bramel-Cox and Cox 1989; Menkir et al. 1994).

\section{Breeding procedures}

Recurrent selection and pedigree breeding are the two most common methods used in the genetic improvement of both sorghum and pearl millet. The basic requirement of random mating for the application of recurrent selection in pearl millet is met through its natural outbreeding behavior, which is caused by protogynous flowering. In sorghum, random mating is achieved through the application of genetic male sterility. At least seven recessive genes for male sterility have been identified in sorghum, but $m s_{3}$ has been used in nearly all the population improvement programs, because it was the first to be discovered that had few disadvantageous pleiotropic effects. Recurrent selection in both crops allows for efficient handling of germplasm in breeding programs and, in Asia and Africa, it is primarily intended for the development of varieties. Much greater application of various recurrent selection methods has occurred in pearl millet than in sorghum. For instance, ICRISAT programs in Asia and Africa have developed about 50 pearl millet composites of diverse origin and various morphological characteristics (Rai and Anand Kumar 1994) and have improved these for various selection cycles. A pearl millet study using population-cycle bulks of four composites improved for 4-5 cycles showed $3.6-4.9 \%$ genetic gains per cycle in grain yield with no adverse changes in plant height and maturity in three of the composites (Rattunde and Witcombe 1993). Pearl millet is amenable to all forms of recurrent-selection schemes. However, a comparative study in pearl millet found no significant difference among various recurrent selection procedures and concluded that the choice of a recurrent-selection scheme should be determined largely by the objective of the program and the availability of resources
(Singh et al. 1988). Several random-mating populations of sorghum were developed at ICRISAT, but only a few have been systematically studied and documented. Rattunde et al. (1997) showed an improvement of $13 \%$ in grain yield after two cycles of $S_{1}$ selection in a population (most of this improvement occurred in the first cycle).

Pedigree breeding from populations that have mostly been derived from single crosses is the most common method in breeding hybrid parents of both sorghum and pearl millet (Andrews et al. 1997). This approach continues to be quite successful, although it has obvious effects in that it narrows the genetic base of hybrid cultivars. Pedigree breeding using composites as base populations has the potential to $(i)$ accelerate the genetic gains for yield in hybrids and ( $i i)$ broaden the genetic base of hybrid cultivars that would contribute to yield stability. However, composites will be used for pedigree breeding of hybrid parents only when they fulfill the basic traits required of hybrid parents. The development of composites specifically targeted for breeding hybrid parents is a relatively recent development in pearl millet. However, a diverse range of existing composites, developed primarily for breeding OPVs, can serve as base material for deriving partial inbreds, some of which can be used directly as hybrid parents, but most of which will find use in crosses to further diversify hybrid-parent breeding programs.

\section{Cultivar development}

Both OPVs (just varieties in sorghum) and hybrids are commercially grown in sorghum as well as in pearl millet. In both crops, the highest-yielding hybrids have about $15-30 \%$ grain yield advantage over the best varieties of comparable maturity. A variety in sorghum is an advanced generation progeny (generally $\mathrm{F}_{6}-\mathrm{F}_{7}$ or $\mathrm{S}_{5}-\mathrm{S}_{6}$ ) that is highly homozygous and homogeneous. Thus, a sorghum variety has a stable genotypic structure, with little chance of significant genetic change over time except that due to outcrossing or spontaneous mutation. In contrast, an OPV in pearl millet is a highly heterozygous and heterogeneous population, open to significant genetic changes. Pearl millet OPVs, bred from single progenies (full-sib or $\mathrm{S}_{1}-\mathrm{S}_{2}$ ), do not perform well and, hence, are not under cultivation. Wider genetic variability is needed to maintain vigor over generations. Thus, pearl millet varieties are often developed by balanced random mating of 5-10 full-sib or $S_{1}-S_{2}$ progenies. Several OPVs developed on the basis of this procedure have been released (e.g., WC-C75, ICTP 8203, and Raj 171) and are widely grown. Provided that some characters of greatest visual appeal, such as flowering, plant height, panicle size and shape, and grain size, shape, and color, can be kept sufficiently uniform for varietal identification purposes, even larger numbers of progenies $(>50)$ can be used in breeding productive OPVs of pearl millet (e.g., ICMV 155, ICMV 221, and ICMV 88908 (= Okashana 1)). Unlike the case of sorghum, within a pearl millet variety there is continual reorganization of variability generating a narrow range of phenotypes within a recognizable norm. Mild mass selection during the seed increase of a variety is a useful exercise to maintain this norm. Genetic shift is likely to occur when a pearl millet variety is grown in a different environment. A corollary of this is that a pearl millet variety can be fine-tuned for its adaptation and productivity to a range of related environments, but seed stocks 
for each of these environments would then have to be maintained separately.

There are several other advantages of pearl millet varieties over sorghum varieties. Pearl millet varieties have seed yields 2-3 times higher than the inbred seed parents; in sorghum, improved varieties outyield improved seed parents by no more than $50 \%$. Intrapopulation variability in pearl millet helps in the genetic management of several diseases. For instance, genetic heterogeneity confers durable resistance to downy mildew, and a variation in flowering confers pollenbased escape from ergot and smut infection; this contrasts well with frequent downy mildew epidemics on single-cross hybrids of pearl millet and their greater vulnerability to ergot and smut. In consequence, improved pearl millet OPVs are readily acceptable to farmers and are easier to multiply and, hence, have carved a niche for themselves even in India, where hybrids are the preferred cultivars. In part, this may have to do with the memory of downy mildew epidemics on hybrids in India.

Commercial hybrids of both sorghum and pearl millet are produced using cytoplasmic-nuclear male sterile (CMS) lines and currently, in both crops, only one CMS system, designated $\mathrm{A}_{1}$, is predominantly used worldwide (Schertz et al. 1997). All the commercial grain hybrids in sorghum and almost all those in pearl millet are single-cross hybrids. Three-way hybrids can be produced in both crops, but they are less likely to be adopted in sorghum, because sorghum growers are relatively more conscious of the morphological uniformity of single-cross hybrids, and the seed yield advantage of the male-sterile $F_{1}$ s over male-sterile inbreds is much less in sorghum than in pearl millet.

In pearl millet, there are two other types of hybrids that cannot be produced in sorghum. The first one is a topcross hybrid, which is produced by crossing an OPV with an inbred-seed parent. This type of hybrid achieves a compromise between the positive attributes of both OPVs (yield stability and durable disease resistance) and single-cross hybrids (phenotypic uniformity and higher grain yield). The second type is an interpopulation hybrid, also called an intervarietal hybrid. This type of hybrid can be produced commercially by crossing an OPV with a male-sterile population. Interpopulation hybrids would be phenotypically as variable as OPVs but could produce 32-45\% greater yields (Ouendeba et al. 1993). The higher seed yields and greater durability in downy mildew resistance of population seed parents would make them an economically more attractive proposition for commercial utilization of interpopulation hybrids than inbred seed parents.

One topcross hybrid, CMH 88088, based on a CMS inbred line is under commercial production in Maharashtra State in India (Talukdar et al. 1996) and another one, JBH 1 (= GICH 501), has been released by the Madhya Pradesh Variety Release Committee (Hash et al. 1997). The protogynous flowering of pearl millet essentially makes its panicle equivalent to a male-sterile until it sheds its own pollen, by which time it would be pollinated by pollen from other plants. This trait can be effectively used to breed topcross hybrids that might be more desirable in ergot- and smutprone areas than topcross hybrids developed on CMS-based inbred seed parents (Andrews et al. 1993). This type of hybrid may be a better option for Africa, because of its po- tential yield stability and durable disease resistance. Interpopulation hybrids have not been commercialized so far, but this now appears possible, as the feasibility of breeding male-sterile populations using the $\mathrm{A}_{4} \mathrm{CMS}$ system has been demonstrated (Rai and Rao 1995).

The genetic base of hybrids in both crops in India is broader today than it was a few decades ago, especially in pearl millet. Some of the new CMS systems (i.e., $\mathrm{A}_{4}$ and $\mathrm{A}_{5}$ ) in pearl millet, for which much more of the germplasm is in the maintainer class than in the $\mathrm{A}_{1}$ system, offer the opportunity to accelerate the diversification of the genetic base of pearl millet seed parents (Hanna 1989; Rai and Rao 1996; Rai et al. 1996). These two new CMS systems also appear to have more stable male sterility than the $\mathrm{A}_{1} \mathrm{CMS}$ system.

In hybrid breeding of both crops, the challenge lies in breeding parental lines with improved performance per se and general combining ability. Sorghum suffers relatively less from inbreeding depression during line development than does pearl millet. Thus, breeding for seed yield in pearl millet parental lines, especially seed parents, is a higher priority and a greater challenge. The lines in both crops must also satisfy other requirements to become hybrid parents, for instance, good fertility restoration ability of R lines, complete male sterility maintenance ability in B lines, and acceptable levels of resistance to downy mildew in pearl millet and leaf blight in sorghum. On top of the above features, there should also be adequate diversity for morphophysiological and grain traits among the lines to satisfy the diverse needs of farmers. It is only after this has been achieved that evaluation for general combining ability starts, mostly at the $\mathrm{F}_{5}-\mathrm{F}_{6}$ or $\mathrm{S}_{4}-\mathrm{S}_{5}$ stage. Fortunately, there is a positive relationship between the performance of lines per se and their general combining ability for seed yield in sorghum. However, in pearl millet, these traits have often been found to be either uncorrelated or positively correlated (K.N. Rai and D.S. Virk, unpublished data).

\section{Impact and prospects}

About $55 \%$ of the hectarage under sorghum and pearl millet cultivation in India was planted with high-yielding varieties (HYVs) during 1992-1994 (Fig. 1). This nearly doubled the productivity of both crops compared with the pre-HYV era. The area under HYV cultivation continues to rise and so does the productivity, with no yield plateau in sight. In addition, cultivar diversity has increased substantially, leading to more appropriate choices of cultivars being available to farmers, and hence improved yield stability. But these positive changes in adoption scales and cultivar diversity have occurred more in relatively favorable environments and in states with well-developed seed production infrastructure. For instance, Maharashtra State, with a large number of private seed companies and an aggressive state seed corporation, had about 18 improved pearl millet cultivars under various scales of cultivation during the mid-1990s compared with no more than three during the mid-1980s. Similar changes in pearl millet cultivar diversity have occurred in Gujarat State. These two leading states now have $85-90 \%$ of the pearl millet hectarage under HYV cultivation; in Gujarat State this consists mostly of hybrids but, in Maharashtra State, a substantial proportion is still an OPV (ICTP 8203). 
Fig. 1. Three-year means of total area, area under HYVs, and grain yield (kilograms/hectare) in sorghum (-) and pearl millet (--) in India in 1956-1994.

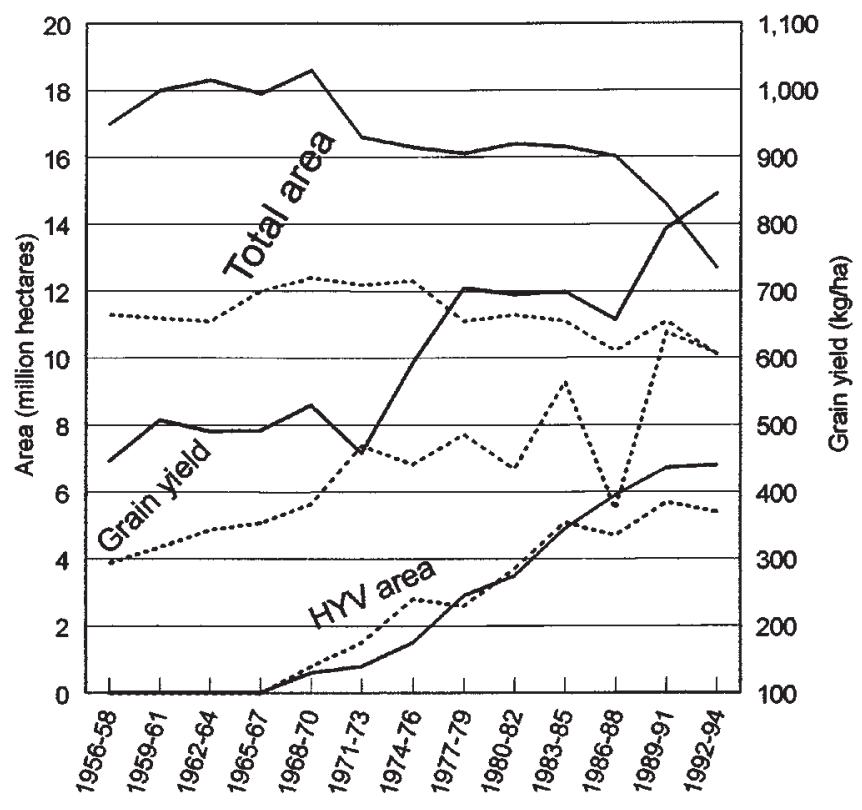

Year

In contrast, Rajasthan State, which has about $40 \%$ of the total pearl millet area in India, much of it in unfavorable (dry and low soil fertility) environments, grows HYVs on $<25 \%$ of the area, because there is limited cultivar development and seed production effort directed toward this area. The adoption of HYVs of rainy season sorghum ranges from $30 \%$ in Karnataka to $90 \%$ in Tamil Nadu (Rana et al. 1997). However, the adoption levels of HYVs of post-rainy-season (rabi) sorghum remain very low. The adoption of sorghum and pearl millet HYVs across most of the African regions, in general, has been insignificant for the same reasons described above for pearl millet in Rajasthan State of India. Andrews and Bramel-Cox (1993) reviewed the achievements of early sorghum and pearl millet breeding efforts in several African countries. Some of the popular sorghum varieties that farmers had adopted included SK 5912 in Nigeria, Framida in Zambia and Zimbabawe, and Serena and Seredo in eastern Africa. Similarly, some of the popular pearl millet OPVs included Ex-Bornu in Nigeria, HKP and CIVT II in Niger, M2D2 and M9D3 in Mali, Souna III in Senegal, Serere $3 \mathrm{~A}$ in Tanzania, Serere $6 \mathrm{~A}$ in Botswana, and Okashana 1 in Namibia. Most of these varieties yielded only 10-20\% more than unimproved locals and were not backed by adequate seed production, which led to their low coverage. The exception was SK 5912, which was being grown on about 100000 ha in Nigeria, not only for high grain yield but also because its grain quality makes it suitable for use in the brewing and infant-food industries. The other exception was Okashana 1 in Namibia, where distinctly earlier maturity, shorter plant type, and larger grain size have essentially made this new OPV an additional component of the production system rather than a replacement for existing landraces.

In recent years, there have been examples of more rapid and relatively larger-scale adoption of HYVs, because either they had a greater grain yield advantage over the unimproved locals or they offered something distinctly different to the farmers than was available in the unimproved locals. But most importantly, in all these instances, variety development backed by significant seed-production efforts played the most critical role. For instance, a pearl millet OPV (ICMV 88908) developed at ICRISAT in India gave yields $45 \%$ higher than the farmers' local varieties in on-farm trials in Namibia in southern Africa. Besides high grain yield, there were three other characters that influenced farmers' perception of this variety: early maturity, drought tolerance, and large seed size. It was released as Okashana 1 in 1990 and rapidly spread to 74000 ha, Obilana et al. (1997), by 1995. Similarly, in Chad in western Africa, sorghum variety S-35 developed at ICRISAT in India gave yields 50\% higher than the farmers' local varieties. Besides its high grain yield, S-35 was preferred for its early maturity and drought tolerance. It was released in 1989 and rapidly spread to 66000 ha by 1995 (A.M. Yapi et al., unpublished data). This variety also performed well in Cameroon, where it was released in 1986 and occupied $33 \%$ of the total sorghum area by 1995 .

Several other promising varieties of sorghum and pearl millet have been developed through collaborative research efforts between ICRISAT and national programs in southern and western Africa (Rai and Anand Kumar 1994; Obilana et al. 1997). Some of these have reached significant levels of adoption. For instance, the sorghum variety Phofu was cultivated on an estimated 22000 ha in Botswana in 1995. Another sorghum variety, SV 2, was cultivated on 40000 ha in Zimbabwe. Three pearl millet varieties that have reached significant levels of adoption in southern Africa are PMV 2 in Zimbabwe and Lubasi and Kaufela in Zambia; PMV 2 was cultivated on 35000 ha, Lubasi was grown on 20000 ha, and Kaufela was grown on 10000 ha. In western Africa, pearl millet variety ITMV 8001, developed in Niger, was found to be promising in Chad, where it rapidly spread to 45000 ha, Obilana et al. (1997).

Research shows that a greater impact may be made on sorghum and pearl millet productivity in Africa through hybrid cultivars, as occurred earlier in India. House et al. (1997) summarized yield-trial results of several studies in Africa, and showed that, generally, hybrid grain had yield advantages of $25-60 \%$ over OPVs. A similar summary for pearl millet (Rai et al. 1997b) showed that topcross and interpopulation hybrids had a 30-50\% grain yield advantage over improved OPVs. Except for South Africa, the only sorghum or pearl millet hybrid grown on a commercial scale anywhere in Africa is the sorghum hybrid Hageen-Durra-1, which was released in Sudan in 1983, and BSH 1 released in Botswana in 1994. The BSH 1 is a white grained hybrid that was expected to be grown on 10 000-15000 ha (about 11$17 \%$ of the total sorghum area) in Botswana. During the drought year of 1994, this hybrid gave $85 \%$ higher yields than unimproved locals under dryland conditions (House et al. 1997). It was planted on 29000 ha in 1995 and enough seed was produced to plant 250000 ha in 1997. A diverse range of improved breeding lines and (or) populations and CMS systems now available in sorghum and pearl millet provide opportunities to repeat the Hageen-Durra-1 story elsewhere in Africa. 
Table 3. Essential amino acid composition ${ }^{a}$ and protein content of sorghum and pearl millet grains (Andrews and Kumar 1992).

\begin{tabular}{|c|c|c|c|c|c|c|c|c|c|c|c|c|c|c|c|c|}
\hline & \multicolumn{2}{|c|}{ Lysine } & \multicolumn{2}{|c|}{ Threonine } & \multicolumn{2}{|c|}{ Valine } & \multicolumn{2}{|c|}{$\begin{array}{l}\text { Methionine + } \\
\text { cysteine } \\
\end{array}$} & \multicolumn{2}{|c|}{ Isoleucine } & \multicolumn{2}{|c|}{ Leucine } & \multicolumn{2}{|c|}{$\begin{array}{c}\text { Phenylalanine }+ \\
\text { tyrosine }\end{array}$} & \multicolumn{2}{|c|}{ Protein $(\%)$} \\
\hline & $n$ & Mean & $n$ & Mean & $n$ & Mean & $n$ & Mean & $n$ & Mean & $n$ & Mean & $n$ & Mean & $n$ & Mean \\
\hline Pearl millet & 280 & 2.84 & 29 & 4.07 & 29 & 6.01 & 29 & 2.71 & 29 & 4.56 & 29 & 12.42 & 29 & 8.49 & 280 & 12.30 \\
\hline
\end{tabular}

${ }^{a}$ Given as mean $\mathrm{g} \cdot 16 \mathrm{~g}^{-1} \mathrm{~N}$ for $n$ (number of samples).

Conventional breeding approaches will continue to make significant contributions to the genetic enhancement of productivity in sorghum and pearl millet. However, the efficiency of such efforts can be increased considerably through the application of biotechnological tools to address areas as diverse as the determination of heterotic patterns for more rational utilization of the germplasm in hybrid-parent development and the genetic manipulation of traits that are too susceptible to the unpredictable environmental variations that are so characteristic of semi-arid tropical regions. The transfer of genes to provide increased growth rate; resistance to shoot pests, mold, S. hermonthica, and drought; and industrial qualities will require molecular marker assisted selection to complement conventional breeding methods. Judging from the extensive research efforts and new developments in the most favored grain crops in the 20th century, and considering the vast amount of untapped variability in the germplasm, the scope and potential for further genetic improvement in sorghum and pearl millet are enormous.

Sorghum and pearl millet will continue to be important food grains for farmers in the dry regions of the semi-arid tropics in India and Africa. Suitable areas for the expansion of favored cereals, such as rice, wheat, barley, and maize, have dwindled. Therefore, sorghum and pearl millet, which have exceptional quality of growth and adaptation in marginal environments, have the potential of becoming more important crops for feeding the growing population in these regions in the 21 st century. In southeast Asia, Latin America, and other fast-developing regions, as well as in many countries of the developed world, the demand for sorghum as a feed will continue to increase, and pearl millet may also have great potential for such purposes (Andrews and Kumar 1992; Bramel-Cox et al. 1995). Results of several feeding trials indicate that pearl millet is equivalent to maize as duck, broiler, and pig rations, but superior to maize when fed to laying hens and quails (Andrews et al. 1996). Substituting pearl millet for maize in the diet of laying hens has been shown to increase the percentage of mono-unsaturated and $n-3$ polyunsaturated fatty acids and decrease $n-6$ fatty acids, providing a good opportunity to produce healthier "designer" eggs (Collins et al. 1997). The use of sorghum and pearl millet in industry will increase as and when more cost-effective grain processing and food-feed technologies are developed. The increased use of sorghum and pearl millet grains will depend on their feed value and price relative to competing crops such as maize and barley and, therefore, it is imperative to increase the productivity of these two crops (ICRISAT and the Food and Agriculture Organization (FAO) 1996).

Pearl millet has a higher level of grain protein and a better amino acid profile than sorghum (Table 3 ). The digestibility of sorghum protein is relatively poor, because cross-linked prolamine levels are relatively higher in sorghum than in pearl millet. The digestibility problem is further complicated by the presence of polyphenols as condensed tannins in some brown grain sorghums (those with a testa). In sorghum, two genetic mutants, one occurring naturally and another one induced, have been identified that increase the lysine content of the sorghum endosperm and improve the protein quality in the grain (Singh and Axtell 1973; Axtell and Ejeta 1990). Utilizing the natural high-lysine mutant in sorghum breeding has been frustrating, since it results in shriveled endosperm, but using the induced mutant with plump grains (P721Q) and its derivatives has resulted in promising lines combining high lysine with relatively vitreous endosperm and high yields (Axtell and Ejeta 1990). No high-lysine mutants have been identified yet in pearl millet, though they must exist. One pearl millet study has shown that it should be possible to select for increased protein without sacrificing grain yield (Kumar et al. 1983), while another has identified genotypes with high protein content ranging from 14 to $19 \%$ (Singh et al. 1987). At higher protein levels, the percentage of lysine in protein decreases, but in the grain sample it still increases. The fatty acid composition of the free and bound lipids in pearl millet and sorghum is quite similar, but total lipid levels are considerably higher in pearl millet, which contributes to its higher caloric value (Hulse et al. 1980). However, this higher free lipid level also contributes to rancidity in pearl millet, when grain or meal moisture is high during storage. Also, pearl millet grains exhibit higher levels of calcium and iron than sorghum.

Genetic enhancement programs for sorghum and pearl millet will need to take note of changes in climatic and socio-economic conditions and emerging new opportunities. For example, the reduction in the length of the growingseason in Niger by 5-20 days since 1960 and a decline in August rainfall of about $40 \%$ require development of relatively early maturing cultivars. The interaction of such cultivars with increased panicle pest incidence remains to be resolved. Similar reduction in growing-season length in parts of Namibia also requires development of early-maturing cultivars. Another example is the increasing area being planted with pearl millet for summer cultivation under irrigated conditions in Gujarat State in India, where mostly early-maturing cultivars are preferred, although dual-purpose late-maturing cultivars are preferred in some regions of this state.

In recent years, there has been considerable increase in the forage and feed value of sorghum in India, leading to a new thrust toward developing dual-purpose cultivars. Considerable sorghum and pearl millet area, especially in Africa, has highly acidic soils $(\mathrm{pH}<5.0)$. Genetic variability for tol- 
erance to acid soil toxicity has been observed in both crops, but pearl millet has been found to be far more tolerant than sorghum (Clark et al. 1990; Flores et al. 1991). Breeding sorghum and pearl millet cultivars with tolerance to this trait will not only increase yields of these crops in Africa, but will also lead to sorghum yield increases in Latin America and to pearl millet being considered as a potential grain crop for this region. Pearl millet is already finding a place in Brazil as a component of an acid soil tolerant mulch in a notill soybean production system (Uemura et al. 1997), and the area sown with this crop in Latin America (currently about 2.0 million ha) is growing rapidly.

Unlike rice, wheat, barley, and maize, which are used both for food and industrial purposes, sorghum and pearl millet have so far remained traditional food crops of subsistence farmers. In Nigeria, however, sorghum has been widely used during the last decade in the beverage industry as a substitute for barley malt. As a result, improved malting and brewing quality have become significant attributes of sorghum cultivars. Similarly, pearl millet is providing an economic substitute for maize in poultry rations in Tamil Nadu State in India. It shows that, if these crops can attract increased industrial uses, for which they have considerable potential, implications for future genetic enhancement could be challenging.

\section{Acknowledgements}

We thank Dr. C.T. Hash for reviewing the manuscript and offering several useful suggestions. Part of this work was done while K.N.R. was a visiting scientist at the University of Nebraska. Partial funding support from INTSORMIL (International Sorghum and Millet CRSP) is gratefully acknowledged. Approved as ICRISAT Conference Paper No. 1382.

\section{References}

Andrews, D.J., and Anand Kumar, K. 1996. Use of the West African pearl millet landrace Iniadi in cultivar development. In Plant Genetics Resources Newsletter No. 105. The Crop Ecology and Genetic Resources Unit, Plant Production and Protection Division of the Food and Agriculture Organization of the United Nations (Rome, Italy) and the International Board for Plant Genetic Resources. pp. 15-22.

Andrews, D.J., and Bramel-Cox, P.J. 1993. Breeding cultivars for sustainable crop production in low input dryland agriculture in the tropics. In International crop science I. Edited by D.R. Buxton, R. Shibles, R.A. Forsberg, B.L Blad, K.H. Asay, G.M. Paulsen, and R.F. Wilson. Crop Science Society of America, Madison, Wis. pp. 211-223.

Andrews, D.J., and Kumar, K.A. 1992. Pearl millet for food, feed and forage. Adv. Agron. 48: 89-139.

Andrews, D.J., Kiula, B., and Rajewski, J.F. 1993. The use of protogyny to make hybrids in pearl millet. In New crops. Edited by J. Janick and J. Simpson. John Wiley \& Sons, New York. pp. 208-210.

Andrews, D.J., Hanna, W.W., Rajewski, J.F., and Collins, V.P. 1996. Advances in grain pearl millet utilization and production research. In Progress in new crops: new opportunities, new technologies. Edited by J. Janick. American Society for Horticultural Science (ASHS) Press, Alexandria, Va. pp. 170-176.
Andrews, D.J., Ejeta, G., Gilbert, M., Goswami, P., Anand Kumar, K., Maunder, A.B., Porter, K., Rai, K.N., Rajewski, J.F., Reddy, B.V.S., Stegmeier, W., and Talukdar, B.S. 1997. Breeding hybrid parents. In Proceedings of an International Conference on the Genetic Improvement of Sorghum and Pearl Millet, held at Lubbock, Texas, 22-27 September 1996. International Sorghum and Millet Research (INTSORMIL) - International Crops Research Institute for the Semi-arid Tropics (ICRISAT). pp. 173-187.

Axtell, J.D., and Ejeta, G. 1990. Improving sorghum grain protein quality by breeding. In Proceedings of an International Conference on Sorghum Nutritional Quality. Edited by G. Ejeta. Purdue University, West Lafayette, Ind. pp. 117-125.

Bandyopadhyay, R., Mughogho, L.K., and Prasada Rao, K.E. 1988. Sources of resistance to sorghum grain mold. Plant Dis. 72: 504-508.

Bidinger, F.R., and Mahalakshmi, V. 1993. Selection for drought tolerance. In The 1992 annual report on the cereals program of the International Crops Research Institute for the Semi-arid Tropics (ICRISAT). ICRISAT, Patancheru, India. pp. 57-59.

Bramel-Cox, P.J., and Cox, T.S. 1989. Use of wild germplasm in sorghum improvement. In Proceedings of the 43rd Annual Corn and Sorghum Industry Research Conference, held at Chicago, Ill. American Seed Trade Association, Washington, D.C. pp. 1326.

Bramel-Cox, P.J., Kumar, K.A., Hancock, J.D., and Andrews, D.J. 1995. Sorghum and millets for forage and feed. In Sorghum and millets: chemistry and technology. Edited by D.A.V. Dendy. American Association of Cereal Chemists, Inc., St. Paul, Minn. pp. 325-364.

Brunken, J., de Wet, J.M.J., and Harlan, J.R. 1977. The morphology and domestication of pearl millet. Econ. Bot. 31: 163-174.

Clark, R.B., Flores, C.I., Gourley, L.M., and Duncan, R.R. 1990. Mineral element concentrations and grain yield of sorghum (Sorghum bicolor) and pearl millet (Pennisetum glaucum) grown on acid soil. J. Plant. Nutr. 13: 391-396.

Collins, V.P., Cantor, A.H., Pescatore, A.J., Straw, M.L., and Ford, M.J. 1997. Pearl millet in layer diets enhances egg yolk n-3 fatty acids. Poult. Sci. 76: 326-330.

de Wet, J.M.J. 1978. Systematics and evolution of Sorghum sect. Sorghum (Gramineae). Am. J. Bot. 65: 477.

Eberhart, S.A., Bramel-Cox, P.J., and Prasada Rao, K.E. 1997. Preserving genetic resources. In Proceedings of an International Conference on the Genetic Improvement of Sorghum and Pearl Millet, held at Lubbock, Texas, 22-27 September 1996. International Sorghum and Millet Research (INTSORMIL) - International Crops Research Institute for the Semi-arid Tropics (ICRISAT). pp. 504-516.

Ejeta, G., Butler, L.G., Hess, D.E., Obilana, T., and Reddy, B.V. 1997. Breeding for Striga resistance in sorghum. In Proceedings of an International Conference on the Genetic Improvement of Sorghum and Pearl Millet, held at Lubbock, Texas, 22-27 September 1996. International Sorghum and Millet Research (INTSORMIL) - International Crops Research Institute for the Semi-arid Tropics (ICRISAT). pp. 504-516.

Flores, C.I., Clark, R.B., and Gourley, L.M. 1991. Genotypic variation of pearl millet for growth and yield on acid soil. Field Crops Res. 26: 347-354.

Fussell, L.K., Bidinger, F.R., and Bieler, P. 1991. Crop physiology and breeding for drought tolerance: research and development. Field Crops Res. 27: 183-199.

Hanna, W.W. 1987. Utilization of wild relatives of pearl millet. In Proceedings of an International Pearl Millet Workshop, held at the International Crops Research Institute for the Semi-arid Tropics (ICRISAT), India, 7-11 April 1996. Edited by J.R. 
Witcombe and S.R. Beckerman. ICRISAT, Patancheru, India. pp. 33-42.

Hanna, W.W. 1989. Characteristics and stability of a new cytoplasmic-nuclear male sterile source in pearl millet. Crop Sci. 29: $1457-1459$.

Hanna, W.W. 1992. Utilization of germplasm from wild species. In Desertified grasslands: their biology and management. Edited by G.P. Chapman. Academic Press, London. pp. 251-257.

Hanna, W.W., and Lovell, G. 1995. Pennisetum germplasm in the U.S.A. In International Sorghum and Millets Newsletter No. 36. pp. 1-3.

Harlan, J.R., and de Wet, J.M.J. 1971. Towards a rational classification of cultivated plants. Taxon, 20: 509-517.

Harlan, J.R., and de Wet, J.M.J. 1972. A simplified classification of cultivated sorghums. Crop Sci. 12: 172-176.

Hash, C.T., Witcombe, J.R., Thakur, R.P., Bhatnagar, S.K., Singh, S.D., and Wilson, J.P. 1997. Breeding for pearl millet disease resistance. In Proceedings of an International Conference on the Genetic Improvement of Sorghum and Pearl Millet, held at Lubbock, Texas, 22-27 September 1996. International Sorghum and Millet Research (INTSORMIL) - International Crops Research Institute for the Semi-arid Tropics (ICRISAT). pp. 337-372.

House, L.R., Verma, B.N., Ejeta, G., Rana, B.S., Kapran, I., Obilana, A.B., and Reddy, B.V.S. 1997. Developing countries breeding and potential of hybrid sorghum. In Proceedings of an International Conference on the Genetic Improvement of Sorghum and Pearl Millet, held at Lubbock, Texas, 22-27 September 1996. International Sorghum and Millet Research (INTSORMIL) - International Crops Research Institute for the Semi-arid Tropics (ICRISAT). pp. 84-96.

Hulse, J.H., Laing, E., and Pearson, D.D. 1980. Sorghum and the millets: their composition and nutritive value. Academic Press, New York.

International Crops Research Institute for the Semi-Arid Tropics and Food and Agriculture Organization of the United Nations. 1996. The world sorghum and millet economies: facts, trends and outlook. International Crops Research Institute for the Semi-arid Tropics (ICRISAT), Patancheru, India. p. 68.

Kumar, K.A., Gupta, S.C., and Andrews, D.J. 1983. Relationship between nutritional quality characters and grain yield in pearl millet. Crop Sci. 23: 232-235.

Lagoke, S.T.O., Parkinson, V., and Agunbiade, R.M. 1991. Parasitic weeds and control methods in Africa. In Combating Striga in Africa: Proceedings of an International Workshop Organized by the International Institute of Tropical Agriculture (IITA), the International Crops Research Institute for the Semi-arid Tropics (ICRISAT), and the International Development Research Centre (IDRC), 22-24 August 1988. IITA, Ibadan, Nigeria. pp. 3-14.

Mahalakshmi, V., and Bidinger, F.R 1985. Water stress and time of floral initiation in pearl millet. J. Agric. Sci. 105: 437-445.

Menkir, A., Bramel-Cox, P.J., and Witt, M.D. 1994. Comparisons of methods for introgressing exotic germplasm into adapted sorghum. Theor. Appl. Genet. 89: 233-239.

Murty, D.S., and Kumar, K.A. 1995. Traditional uses of sorghum and millets. In Sorghum and millets: chemistry and technology. Edited by D.A.V. Dendy. American Association of Cereal Chemists, Inc., St. Paul, Minn. pp. 185-221.

Obilana, A.B., Monyo, E.S., and Gupta, S.C. 1997. Impact of genetic improvement in sorghum and pearl millet: developing countries experience. In Proceedings of an International Conference on the Genetic Improvement of Sorghum and Pearl Millet, held at Lubbock, Texas, 22-27 September 1996. International Sorghum and Millet Research (INTSORMIL) - International
Crops Research Institute for the Semi-arid Tropics (ICRISAT). pp. 119-141.

Ouendeba, B., Ejeta, G., Nyquist, W.E., Hanna, W.W., and Kumar, K. 1993. Heterosis and combining ability among African pearl millet landraces. Crop. Sci. 33: 735-739.

Pande, S., Thakur, R.P., Karunakar, R.I., Bandyopadhyay, R., and Reddy, B.V.S. 1994. Development of screening methods and identification of stable resistance to anthracnose in sorghum. Field Crops Res. 38: 157-166.

Rai, K.N., and Anand Kumar, K. 1994. Pearl millet improvement at ICRISAT - an update. International Sorghum and Millets Newsletter No. 35. pp. 1-29.

Rai, K.N., and Rao, A.S. 1995. Commercial feasibility of growing interpopulation hybrids in pearl millet. International Sorghum and Millets Newsletter No. 36. pp. 49-50.

Rai, K.N., and Rao, A.S. 1996. A new CMS system and its restorers in pearl millet. In Proceedings of an International Crop Science Congress, held at New Delhi, India, 17-24 November 1996. Abstract P5-0018.

Rai, K.N., Virk, D.S., Harinarayana, G., and Rao, A.S. 1996. Stability of male-sterile sources and fertility restoration of their hybrids in pearl millet. Plant Breed. 115: 494-500.

Rai, K.N., Appa Rao, S., and Reddy, K.N. 1997a. Pearl millet. In Biodiversity in trust: conservation and use of plant genetic resources in CGIAR (Consultative Group on International Agricultural Research) centers. Chapter 17. Edited by D. Fuccillo, L. Sears, and P. Stapleton. Cambridge University Press, U.K. pp. 243-258.

Rai, K.N., Anand Kumar, K., Andrews, D.J., Gupta, S.C., and Ouendeba, B. 1997b. Breeding pearl millet for grain yield and stability. In Proceedings of an International Conference on the Genetic Improvement of Sorghum and Pearl Millet, held at Lubbock, Texas, 22-27 September 1996. International Sorghum and Millet Research (INTSORMIL) - International Crops Research Institute for the Semi-arid Tropics (ICRISAT). pp. 71-83.

Rana, B.S., Swarnalata, K., and Rao, M.H. 1997. Impact of genetic improvement on sorghum productivity in India. In Proceedings of an International Conference on the Genetic Improvement of Sorghum and Pearl Millet, held at Lubbock, Texas, 22-27 September 1996. International Sorghum and Millet Research (INTSORMIL) - International Crops Research Institute for the Semi-arid Tropics (ICRISAT). pp. 142-165.

Rattunde, H.F., and Witcombe, J.R. 1993. Recurrent selection for increased grain yield and resistance to downy mildew in pearl millet. Plant Breed. 110: 63-72.

Rattunde, H.F.W., Weltzein, R.E., Bramel-Cox, P.J., Kofoid, K., Hash, C.T., Schipprack, W., Stenhouse, J.W., and Presterl, T. 1997. Population improvement of pearl millet and sorghum: current research, impact and issues for implemetation. In Proceedings of an International Conference on the Genetic Improvement of Sorghum and Pearl Millet, held at Lubbock, Texas, 22-27 September 1996. International Sorghum and Millet Research (INTSORMIL) - International Crops Research Institute for the Semi-arid Tropics (ICRISAT). pp. 188-212.

Rosenow, D.T., Ejeta, G., Clark, L.E., Gilbert, M.L., Henzell, R.G., Borrell, A.K., and Muchow, R.C. 1997. Breeding for pre- and post-flowering drought stress resistance in sorghum. In Proceedings of an International Conference on the Genetic Improvement of Sorghum and Pearl Millet, held at Lubbock, Texas, 22-27 September 1996. International Sorghum and Millet Research (INTSORMIL) - International Crops Research Institute for the Semi-arid Tropics (ICRISAT). pp. 400-411.

Schertz, K.F., Sivaramakrishnan, S., Hanna, W.W., Mullet, J., Sun, Yi., Murty, U.R., Pring, D.R., Rai, K.N., and Reddy, B.V.S. 
1997. Alternate cytoplasms and apomixis of sorghum and pearl millet. In Proceedings of an International Conference on the Genetic Improvement of Sorghum and Pearl Millet, held at Lubbock, Texas, 22-27 September 1996. International Sorghum and Millet Research (INTSORMIL) - International Crops Research Institute for the Semi-arid Tropics (ICRISAT). pp. 213-223.

Sharma, H.C., Taneja, S.L., Leuschner, K., and Nwanze, K.F. 1991. Techniques to screen sorghum for resistance to insects. International Crops Research Institute for the Semi-arid Tropics (ICRISAT) Information Bulletin No. 32. ICRISAT, Patancheru, India.

Sharma, H.C., Agrawal, B.L., Abraham, C.V., Vidyasagar, P., and Nwanze, K.F. 1993. Identification and utilization of resistance to sorghum midge, Contarinia sorghicola. Coq. Crop Prot. 12: $343-350$.

Singh, P., Singh, U., Eggum, B.O., Kumar, K.A., and Andrews, D.J. 1987. Nutritional evaluation of high protein genotypes of pearl millet (Pennisetum americanum (L.) Leeke). J. Sci. Food Agric. 38: 41-48.

Singh, P., Rai, K.N., Witcombe, J.R., and Andrews, D.J. 1988. Population breeding methods in pearl millet improvement (Pennisetum americanum). Agron. Trop. 43: 185-193.

Singh, R., and Axtell, J.D. 1973. High lysine mutant gene $(h l)$ that improves protein quality and biological value of grain sorghum. Crop Sci. 13: 535-539.

Singh, S.D. 1995. Downy mildew of pearl millet. Plant Dis. 79: 545-550.

Singh, S.D., Wilson, J.P., Navi, S.S., Talukdar, B.S., Hess, D.E., and Reddy, K.N. 1997. Screening techniques and sources of re- sistance to downy mildew and rust in pearl millet. International Crops Research Institute for the Semi-arid Tropics (ICRISAT) Information Bulletin No. 48. ICRISAT, Patancheru, India.

Snowden, J.D. 1936. The cultivated races of sorghum. Adlard \& Sons Ltd., London.

Stenhouse, J.W., Prasada Rao, K.E., Gopal Reddy, K., and Appa Rao, S. 1997. Sorghum. In Biodiversity in trust: conservation and use of plant genetic resources in CGIAR (Consultative Group on International Agricultural Research) centers. Chapter 17. Edited by D. Fuccillo, L. Sears, and P. Stapleton. Cambridge University Press, U.K. pp. 292-308.

Talukdar, B.S., Singh, S.D., and Prakash Babu, P.P. 1996. Prospects of topcross hybrids in increasing and stabilizing grain yield in pearl millet. Crop Improv. 23: 147-150.

Thakur, R.P., King, S.B., Rai, K.N., and Rao, V.P. 1992. Identification and utilization of smut resistance in pearl millet. International Crops Research Institute for the Semi-arid Tropics (ICRISAT) Research Bulletin No. 16. ICRISAT, Patancheru, India.

Thakur, R.P., Rai, K.N., King, S.B., and Rao, V.P. 1993. Identification and utilization of ergot resistance in pearl millet. International Crops Research Institute for the Semi-arid Tropics (ICRISAT) Research Bulletin No. 17. ICRISAT, Patancheru, India.

Uemura, Y., Urben Filho, G., and Netto, D.A.M. 1997. Pearl millet as a cover crop for no-till soybean production in Brazil. In International Sorghum and Millets Newsletter No. 38. pp. 141-143. 